Tarih Kültür ve Sanat Araştırmaları Dergisi

Revue des Recherches en Histoire Culture et Art مجلة البحوث التاريخبة و الثقافية والفنية
Vol. 7, No. 4, November 2018

Copyright (C) Karabuk University http://kutaksam.karabuk.edu.tr

\title{
DOI: 10.7596/taksad.v7i4.1824
}

Citation: Akbarova, G., Dyganova, E., Shirieva, N., \& Adamyan, A. (2018). The Technology of Scientific Creativity in the Professional Training of the Music Teacher. Journal of History Culture and Art Research, 7(4), 138-145. doi:http://dx.doi.org/10.7596/taksad.v7i4.1824

\section{The Technology of Scientific Creativity in the Professional Training of the Music Teacher}

\author{
Gulnaz Akbarova ${ }^{1}$, Elena Dyganova ${ }^{2}$, \\ Nadežda Shirieva ${ }^{3}$, Anna Adamyan ${ }^{4}$
}

\begin{abstract}
New realities of the modern educational space make it necessary to equip future music teachers with technologies of scientific creativity based on independent research activity. Having identified the problem areas, the authors propose the solution to the systemic organization of the independent research activity of the student subject to the specificity of musical and pedagogical education in accordance with the requests of the society.

During the research, pedagogical possibilities of independent research and creative work of the student were revealed; the characteristics of the steps in the format of "Written abstract to the vocal-choral composition" are presented; a set of pedagogical support was developed in the form of a teaching aid and a diagnostic technique for determining the level of professionally required results of a music teacher. The theoretical substantiation of the diagnostic function of the written annotation for the vocal-choral product allowed expanding the scientific understanding of the functional of such types of scientific research works.

The introduction of author's developments into the educational process has allowed to obtain convincing results: the understanding by the future teacher of music of the relationship between mastering the methods of scientific knowledge and technology of scientific creativity with personal and professional values and interests; increase of the level of development of the research competence of a musician student; formation of experience of scientific-research and research-creative activity of the future music teacher; increase in the level of formation of a culture of self-education of a teacher of music; and theoretical and practical readiness of future musicians for professional self-actualization in the conditions of real practice.
\end{abstract}

Keywords: Teacher-musician, Research activity, Vocational training, Music education, Summary on the choral work, Culture of self-education.

\footnotetext{
${ }^{1}$ Senior lector, Leo Tolstoy Institute of Philology and Intercultural Communication, Kazan Federal University. Gulnaz.Akbarova@ksu.ru

${ }^{2} \mathrm{PhD}$ in Pedagogy, associate professor, Leo Tolstoy Institute of Philology and Intercultural Communication, Kazan Federal University. Elena.Dyganova@kpfu.ru

${ }^{3}$ Associate professor, Kazan Federal University. taha1978@mail.ru

${ }^{4}$ Candidate of Arts, Assistant Professor/Chair of Music of Pedagogy, Armenian State Pedagogical University after Khachatur Abovyan. E-mail: dirigerdea@mail.ru
} 


\section{Introduction}

Modernization in the system of higher education in Russia has led to a paradigm shift in the training of a teacher of music. Today, the future specialist should be trained in accordance with the professional standards of the Russian Federation and is able to deal with pedagogical, musical performance, design, methodological, organizational and managerial, cultural and educational challenges [1].

To achieve this goal, the higher school implements the restructuring of the vocational education system, which changes the role of the student, the measure of his/her responsibility to the society during the educational process [2]. The new attitude affirms the priority of the independent, self-developing personality of the future specialist, striving to transform him-/herself and reality [3]. The authors of this paper believe that mastering the technology of scientific creativity is an indicator of the culture of selfeducation of a teacher of music [4], therefore, the subject of research was the independent research activity of students.

During his/her professional development, the future musician carries out research work in the form of preparation of reports and participation in scientific and practical seminars and conferences of various status, in competitions of scientific works; performs term papers and theses; prepares the publication of scientific papers in collections and journals.

Note that the content of research activities of the future music teacher is often creative, which is related to professional specifics [5]. Pedagogical observations of the final results of the independent research activities of future musicians made it possible to discover a number of "pressure points":

- lack of understanding of the need to know the methods of scientific knowledge with personal and professional interests and values;

- inadequate awareness of intersubject communications and the lack of comprehensive application of versatile knowledge in the disciplines of pedagogical, psychological, musical-theoretical, and special (conductor, choir, instrumental, vocal) areas;

- insufficient level of mastery of mental operations (analysis, synthesis, comparison, specification, generalization, classification) and skills (modeling, interpretation, forecasting, planning);

- inadequate level of mastering the skills of independent research: goal-setting, working with various sources of information (texts, notes, images, audio, video, etc.), evaluating information material, processing the results.

This problem is in the focus of modern pedagogical science $[6,7,8,9,10]$, but its solution is ambiguous. One of the possible options, as we think, may be the provision of future pedagogical musicians with pedagogical support aimed at the systemic organization of the independent research activity of the student, subject to the specificity of musical and pedagogical education.

In the professional implementation, the teacher of music carries out activities in five areas: constructive, music-performing, communicative-organizational, research activities and individual style of activity [11]. It should be noted that in the professional development of a future specialist, the integration of the indicated types of activities is most evident in the conductor-choir training process. This conclusion made it possible to direct the foreshortening of the research in the direction of studying the pedagogical possibilities of the forms of organization of the research work of students in conductor and choral disciplines. 


\section{Methods}

A personal-activity approach has been chosen as a methodological basis for a specific scientific level, which makes it possible to investigate the process of research work of music students from the standpoint of assessing the achievement of results of activities in reliance on the provisions of a number of related sciences (psychology, pedagogy, and music) $[12,13,14]$ and a competence approach that provides research on the results of the professional development of a music teacher in accordance with educational standards $[15,16]$.

Among the methods, the following were applied: the formulation of problems and the construction of hypotheses; analysis of research materials on the research problem and regulatory and legislative documents of the Russian Federation in the field of education; synthesis and generalization of theoretical conclusions; modeling; pedagogical observations and interviews; systematic and qualitative analysis of the results of research activities of music students on the basis of expert evaluation of works [17].

\section{Results and Discussion}

During the conductor-choir training the future musician carries out independent work of a problemresearch nature in such forms as complex development of educational repertoire (vocal, instrumental, manual), creation of choral arrangements, implementation of abstracts and methodological developments. The independent research activity of a future musician is carried out in the form of performing a written abstract for a choral piece.

Work on the implementation of written abstracts for a choral piece is carried out gradually. The first stage is a musical-theoretical analysis that includes all the information on the study of the notation text of a choral score with the use of pianoforte, vocal and conductor assimilation of voices, and acoustic analysis.

The second stage is a comprehensive study of the choral piece that assumes, first, a deep understanding of the system of poetic and musical expressiveness in connection with the drama of the choral composition and the embodiment of the artistic image; secondly, the consideration of numerous information about the meaningful and expressive and formative possibilities of various aspects and elements of music and words, that is, the great material accumulated in the field of semantics, grammar, stylistics and the historical evolution of musical and poetic language.

The third stage is the processing of the results obtained in the form of a text of a written abstract for a choral piece. The content is presented in a free form, in the support on the rubrics of the plan for a comprehensive analysis of the choral piece. The work reflects the cause-and-effect relationships revealed between the musical-poetic expressive means, vocal-choral features, and conductor's techniques. The main conclusion is the author's performance interpretation of the choral composition under study.

Being guided by the above-mentioned targets and conclusions on the broad pedagogical capabilities of the research work of music students in the form of a written abstract, we have developed a set of pedagogical support. It includes a manual on the support of independent research work of students and a diagnostic technique for determining the level of professionally necessary results of a teacher of music (see Table 1).

The manual "Independent work of students: the implementation of written abstracts for vocal-choral works" (E.A. Dyganova, N.V. Shirieva) is aimed at organizing the self-education of a young specialist in the process of scientific creative work. The content of the training manual includes sections on the integrated analysis of choral composition, creation of a performance interpretation, course program requirements, samples of text and examples, glossary. The work pays special attention to the problems of overcoming the difficulties encountered by music students, recommendations for independent step-by-step analytical 
work on the choral composition and samples of annotations for vocal-choral works that can serve as guidelines for the performance of such works.

Subject to the broad pedagogical functionality of written abstracts for a vocal and choral composition, where one of the functions is a diagnostic function, an expert evaluation of this independent research work of a future musician allows determining the level of achievement of professionally necessary results.

Table 1. Diagnostic technique for determining the level of professionally required results of a music teacher

\section{LOW LEVEL (20-28 POINTS)}

Description of work
Brief, descriptive characteristics of the choral
piece, performed in the form of answers to
the questions of the proposed plan. An
approximate plan for rehearsal work with a
choir is absent.

Indicators of professionally needed results

- insufficient level of pedagogical, musical and special basic knowledge;

- lack of skills of self-educational activity: goal-setting, working with information sources, evaluating information material, processing the results;

- insufficient level of mastering mental operations (analysis, synthesis, comparison, generalization, classification, etc.);

- lack of ability to create an interpretation of the choral composition on the basis of complex analysis;

- lack of skills for determining musical and pedagogical problems and finding ways to address them

\section{MEDIUM LEVEL (29-34 POINTS)}

\section{Description of work}

Extensive work with the predominance of the analytical section with the revealed cause-effect relationship between the content of the poetic image and the musical means of its expression. Particular attention is paid to the definition of vocal choral difficulties and ways to overcome them; an approximate plan of rehearsal work with a choir with a designation of educational and creative tasks is offered.
Indicators of professionally needed results

- sufficient level of pedagogical, musical and special basic knowledge;

- availability of skills of self-educational activity: goalsetting, working with information sources, evaluating information material, processing the results;

- sufficient level of mastering mental operations (analysis, synthesis, comparison, generalization, classification, etc.);

- availability of ability to create an interpretation of the choral composition on the basis of complex analysis;

- availability of knowledge on the methodology of the rehearsal process;

- availability of skills for determining musical and pedagogical problems and finding ways to address them 


\begin{tabular}{|c|c|}
\hline Description of work & Indicators of professionally needed results \\
\hline $\begin{array}{l}\text { An extensive research work with the } \\
\text { predominance of the analytical section, } \\
\text { which revealed the cause-and-effect } \\
\text { relationship between musical expressive } \\
\text { means, vocal-choral features, conductor } \\
\text { techniques, and methods of rehearsal work. } \\
\text { The conclusions and judgments are backed } \\
\text { up by evidence base in the form of } \\
\text { statements and quotations of authoritative } \\
\text { musicians and researchers on this issue. In } \\
\text { the final section, the role and significance of } \\
\text { the work in question in choral music, its } \\
\text { educational and educational potential are } \\
\text { determined. An author's position is available, } \\
\text { an interpretation of the choral composition is } \\
\text { offered, an approximate plan of rehearsal } \\
\text { work with a choir is available with the } \\
\text { designation of educational and creative tasks } \\
\text { and methods for their solution. }\end{array}$ & $\begin{array}{l}\text { - high level of pedagogical, musical and special basic } \\
\text { knowledge; } \\
\text { - free use of skills of self-educational activity: goal- } \\
\text { setting, working with information sources, evaluating } \\
\text { information material, processing the results; } \\
\text { - fluency in mental operations (analysis, synthesis, } \\
\text { comparison, generalization, classification, etc.); } \\
\text { - availability of ability to create an interpretation of the } \\
\text { choral composition on the basis of complex analysis; } \\
\text { - availability of knowledge on the methodology of the } \\
\text { rehearsal process; } \\
\text { - availability of skills for determining musical and } \\
\text { pedagogical problems and finding ways to address them; } \\
\text { - mastery of the rehearsal process technique }\end{array}$ \\
\hline
\end{tabular}

Assessment of the written works of future musicians is carried out in accordance with the following parameters and evaluation criteria:

- substantive content (reliance on an approximate plan for a comprehensive analysis of a choral piece, reflection of connections between musical and poetic expressive means, vocal-choral features, conductor techniques, etc.);

- style of presentation (correspondence to the scientific style, use of professional terminology, clarity and logic, literacy);

- author's position, originality (personal understanding of the basic idea of a choral piece, availability of a performance interpretation, the existence of an approximate plan for rehearsal work, including performing difficulties and ways to overcome them);

- compliance with the requirements of registration (the presence of five sections: introductory, analytical, final, bibliography, annexes, illustrations of music examples, citation footnotes accompanying the source).

A maximum score of the work of 40 points, an estimate of each parameter - 10 points maximum.

\section{Summary}

Based on the identified opportunities for research work of students in the form of the format "Written abstract to the vocal-choral piece", we propose that this type of scientific creativity, with a certain pedagogical support, will allow solving the following pedagogical tasks: 1) activation of professional thinking and creative potential of future musicians; 2 ) development of self-education culture of future musicians (acquisition of skills and abilities of independent work with music and special literature, mastering of research methods of analysis, comparison, generalization, systematization of facts and conclusions); 3) development of scientific written and oral speech of future musicians; and 4) preparation of future musicians for independent musical and pedagogical activity. 


\section{Conclusion}

Pedagogical monitoring (2016-2018) made it possible to find a positive result of introducing pedagogical support into the educational practice of the university:

- the understanding by the future teacher of music of the relationship between mastering the methods of scientific knowledge and technology of scientific creativity with personal and professional values and interests;

- increase of the level of development of the research competence of a musician student;

- formation of experience of scientific-research and research-creative activity of the future music teacher;

- increase in the level of formation of a culture of self-education of a teacher of music; and

- theoretical and practical readiness of future musicians for professional self-actualization in the conditions of real practice.

The obtained conclusions prove the effectiveness of author's development.

\section{Acknowledgements}

The work is performed according to the Russian Government Program of Competitive Growth of Kazan Federal University.

\section{Footnotes}

[1] Prikaz Ministerstva obrazovaniia I nauki RF ot 4 dekabria 2015 goda N 1426 "Ob utverzhdenii federalnogo gosudarstvennogo obrazovatelnogo standarta vysshego obrazovanii po napravleniiu podgotovki 44.03.01 Pedagogicheskoe obrazovanie (uroven bakalavriata)" [Order from the Ministry of Education and Science of the Russian Federation of "On approval of The Federal State Educational Standard of Higher Education in the direction of preparation 44.03.01 Pedagogical education (Bachelor's programme)" approved December 4, 2015, No 1426]. URL: http://base.garant.ru/71300970/ (accessed on 23.04.2018). (In Russian).

[2] Akhmetshina, E. G., \& Kadyjrova, L. H. (2017). Pedagogical Approaches to the Development System of Artistic Culture of Individual. Revista San Gregorio, 20, Special Edition, December, 189-193.

[3] Salikhova, L. I., Batyrshina, G. I., Safiullina, L. G., \& Abdirakhman, G. B. (2017). Ethnocultural Development of Future Music Teachers in Process of the Tatar Piano Music's Studying. Journal of History Culture and Art Research, 6(6), 159-167. DOI: http://dx.doi.org/10.7596/taksad.v6i6.1336.

[4] Akbarova, G. N., Dyganova, E. A., \& Yavgildina, Z. M. (2016). The Technology of Self-Education in Music Pedagogues' Professional Training. TOJDAC, November Special Edition, 2233-2238. DOI: $10.7456 / 1060 N V S E$

[5] Karkina, S., Fajzrahmanova, L., \& Gluzman, A. (2017). Subject-Oriented Approach in the Professional Formation of the Future Music Teacher. Journal of History Culture and Art Research, 6(4), 1071- 1077. DOI: http://dx.doi.org/10.7596/taksad.v6i4.1120

[6] Carrillo Aguilera, C., \& VilarMonmany, M. (2010). The Profile of the Music Teacher Within the European Higher Education Area: Is a Competence-Based Approach Enough? (Preliminary Results). 4th International Technology, Education and Development Conference (INTED), Valencia, SPAIN. 08-10 March, pp. 3485-3495. 
[7] Kovalev, D. A., Khussainova, G. A., Balagazova, S. T., \& Zhankulb, T. (2016). Formation of Various Competencies in the Process of Training the Future Music Teachers at the Present Stage. International Journal of Environmental and Science Education, 11(11), 4175-4183.

[8] Lennon, M., \& Reed, G. (2012). Instrumental and vocal teacher education: Competences, roles and curricula. Music Education Research, 14(3), 285-308.

[9] Rohwer, D., \& Henry, W. (2004). University teachers' perceptions of requisite skills and characteristics of effective music teachers. Journal of Music Teacher Education, 13(2), 18-27.

[10] Taylor, D. B. (1987). A survey of professional music therapists concerning entry level competencies. Journal of Music Therapy, 24(3), 114-145.

[11] Abdullin, E. B., \& Nikolaeva, E. N. (2004). The theory of music education: a textbook for higher education teachers' training institutions. Moscow: Academia Publishing.

[12] Andreev, V. I. (2013). Laws of creative self-development as the basis of the concept of subjectoriented education. Bulletin of Kazan Technological University, 16(16), 13-16.

[13] Vygotsky, L. S. (1987). Psychology of art. Moscow: Pedagogy.

[14] Kamalova, I. F., Javgildina, Z. M., Salakhov, R. F., \& Salakhova, R. I. (2014). Educational axiological potential of music art for the formation of moral value orientations of student youth. European Journal of Science and Theology, 10(6), 129-137.

[15] Khutorskoi, A. V. (2007). Kompetentsii v obrazovanii: opytproektirovaniia [Competencies in Education: Design Experience]. Moscow: Research and innovation company "INEK".

[16] Medvedev, I. F. (2010). Principle of self-education as a methodological basis of self-educational competence. Bulletin of South Ural State University, 36, 38-41.

[17] Novikov, A. M., \& Novikov, D. A. (2007). Methodology. Moscow: SINTEG.

\section{References}

Abdullin, E. B. \& Nikolaeva, E. N. (2004). The theory of music education: a textbook for higher education teachers' training institutions. Moscow: Academia Publishing.

Akbarova, G. N.; Dyganova, E. A. \& Yavgildina, Z. M. (2016). The Technology of Self-Education in Music Pedagogues' Professional Training. TOJDAC, November Special Edition, 2233-2238. DOI: 10.7456/1060NVSE

Akhmetshina, E. G. \& Kadyjrova, L. H. (2017). Pedagogical Approaches to the Development System of Artistic Culture of Individual. Revista San Gregorio, 20, Special Edition, December, 189-193.

Andreev, V. I. (2013). Laws of creative self-development as the basis of the concept of subject-oriented education. Bulletin of Kazan Technological University, 16(16), 13-16.

Carrillo Aguilera, C. \& VilarMonmany, M. (2010). The Profile of the Music Teacher Within the European Higher Education Area: Is a Competence-Based Approach Enough? (Preliminary Results). 4th International Technology, Education and Development Conference (INTED), Valencia, SPAIN. 08-10 March, pp. 34853495. 
Kamalova, I. F.; Javgildina, Z. M.; Salakhov, R. F. \& Salakhova, R. I. (2014). Educational axiological potential of music art for the formation of moral value orientations of student youth. European Journal of Science and Theology, 10(6), 129-137.

Karkina, S.; Fajzrahmanova, L. \& Gluzman, A. (2017). Subject-Oriented Approach in the Professional Formation of the Future Music Teacher. Journal of History Culture and Art Research, 6(4), 1071- 1077. DOI: http://dx.doi.org/10.7596/taksad.v6i4.1120

Khutorskoi, A. V. (2007). Kompetentsii v obrazovanii: opytproektirovaniia [Competencies in Education: Design Experience]. Moscow: Research and innovation company "INEK".

Kovalev, D. A.; Khussainova, G. A.; Balagazova, S. T. \& Zhankulb, T. (2016). Formation of Various Competencies in the Process of Training the Future Music Teachers at the Present Stage. International Journal of Environmental and Science Education, 11(11), 4175-4183.

Lennon, M. \& Reed, G. (2012). Instrumental and vocal teacher education: Competences, roles and curricula. Music Education Research, 14(3), 285-308.

Medvedev, I. F. (2010). Principle of self-education as a methodological basis of self-educational competence. Bulletin of South Ural State University, 36, 38-41.

Novikov, A. M. \& Novikov, D. A. (2007). Methodology. Moscow: SINTEG.

Prikaz Ministerstva obrazovaniia I nauki RF ot 4 dekabria 2015 goda N 1426 "Ob utverzhdenii federalnogo gosudarstvennogo obrazovatelnogo standarta vysshego obrazovanii po napravleniiu podgotovki 44.03 .01 Pedagogicheskoe obrazovanie (uroven bakalavriata)" [Order from the Ministry of Education and Science of the Russian Federation of "On approval of The Federal State Educational Standard of Higher Education in the direction of preparation 44.03.01 Pedagogical education (Bachelor's programme)" approved December 4, 2015, No 1426]. URL: http://base.garant.ru/71300970/ (accessed on 23.04.2018). (In Russian).

Rohwer, D. \& Henry, W. (2004). University teachers' perceptions of requisite skills and characteristics of effective music teachers. Journal of Music Teacher Education, 13(2), 18-27.

Salikhova, L. I.; Batyrshina, G. I.; Safiullina, L. G. \& Abdirakhman, G. B. (2017). Ethnocultural Development of Future Music Teachers in Process of the Tatar Piano Music's Studying. Journal of History Culture and Art Research, 6(6), 159-167. DOI: http://dx.doi.org/10.7596/taksad.v6i6.1336.

Taylor, D. B. (1987). A survey of professional music therapists concerning entry level competencies. Journal of Music Therapy, 24(3), 114-145.

Vygotsky, L. S. (1987). Psychology of art. Moscow: Pedagogy. 